\title{
News Satire: Giving the News a Memory
}

\author{
Laura Basu
}

Communications and Media department, Goldsmiths, University of London, and the Institute for Cultural Inquiry, Utrecht University , Amsterdam, the Netherlands, l.s.basu@uu.nl, laurabasu.com

\begin{abstract}
It is claimed that journalism is facing a far-reaching crisis, with mainstream news becoming ever less independent and informative, and therefore less trusted by publics. In response to this journalistic crisis, what has been termed the "fifth estate" - news satire - has flourished globally in recent years. A fertile area of scholarship has sprung up around it, arguing that it plays an important role in contemporary democracy. This article aims to contribute to these debates around the social functions of both news and news satire by bringing questions of memory and forgetting to these discussions. Firstly, it argues that, linked to acceleration under capitalism, news is a key site of the production of amnesia, and that this media amnesia has ideological outcomes. Secondly, it shows how television news satires both critique and attempt to make sense of the news, and to some extent counter the amnesiac tendencies of news by giving it a memory. In doing this, to some extent news satires thus resist the ideological work performed by news-forgetting along multiple dimensions. The article explores five memory practices in two news satires: The Daily Show (US) and Newswipe (UK).
\end{abstract}

Keywords: Journalism, Media, News Satire, Memory, Forgetting, Amnesia, Ideology, Democracy, Acceleration, Temporality

Acknowledgement: This research was financially supported by the Netherlands Organisation for Scientific Research (NWO) as part of the project "The Power of Satire" led by Marijke Meijer Drees, and a Marie Skłodowska-Curie fellowship with Justin Lewis at Cardiff School for Journalism, Media and Cultural Studies.

While news is in theory supposed to serve a democratic function, informing citizens of what is happening in the world and thereby enabling them to make informed political decisions, in practice mainstream news is confusing, slippery and disorienting. In the words of British satirist Charlie Brooker in the first episode of his TV series Newswipe, "it's like tuning in to episode 803 of the world's most complex soap opera". This alienating characteristic of news can be identified as a key aspect of what many scholars claim is a far-reaching crisis in journalism, with the advent of "hypercommercialisation" in the neoliberal era and the loss of advertising revenues associated with the move online (McChesney 1999). As a result, it is claimed that mainstream news is becoming ever less independent and informative, and therefore less trusted by publics (see Davies 2009; Fenton 2010; Schifferes 2015). In this sense news potentially plays (not necessarily intentionally) a hegemonic role, helping to preserve the status quo by confounding rather than informing the citizenry. This journalistic crisis has come to a head recently in the outcry over 'fake news' and its possible role in the election of US president Donald Trump. While nowadays 'fake news' is associated with social media, in the US it is in many ways the context of television news, with its extreme political partisanship and its "truthiness" (Jones 2009), that has enabled the spread of 'fake news' and 'alternative facts'. 
In response to this journalistic crisis, what has been termed the "fifth estate" (Sotos 2007) - news satire - has flourished globally in recent years, again online and especially on television. The "fifth estate" in this formulation keeps in check the "fourth estate" - journalism - which is failing in its democratic duties to hold the powerful to account and inform the citizenry. A fertile area of scholarship has sprung up around it (see Jones 2010; Baym and Jones 2012; Gray et al. 2009). Jones (2010) claims that the blossoming of news satire indicates a shift in the West's "regime of truth", with mainstream journalism losing its status as the prime purveyor of reality. Interestingly, if you enter "fake news" into a Google Scholar search, the first page of hits is not related to the false stories circulating on social media but to 'fake news' satires like The Daily Show and The Colbert Report (this is probably in large part due to the much slower tempo of academic publishing compared to popular media). These are a very different animal. Baym (2005) contends that, far from undermining democracy, 'fake news' satires are not fake at all but represent a new kind of journalism advocating a more "deliberative democracy".

This article aims to contribute to these debates around the social functions of both news and news satire by bringing questions of memory and forgetting to these discussions. Firstly, it argues that news is a key site of the production of amnesia and that this amnesia should be thought of as playing a critical role in the ideological work performed by journalism. The first part of the article will outline a typology of news forgetting and connect different types of forgetting found in news content to critical theory on both acceleration and amnesia as a phenomenon of capitalism. Secondly, the article will move on to show how, using humour, television news satires both critique and attempt to make sense of the news, and to some extent counter the amnesiac tendencies of news, by giving it a memory. It will explore a range of memory practices in two news satires, namely The Daily Show (US) and Newswipe (UK).

Curiously, the field of cultural memory studies does not usually engage with the critical theory on amnesia. Furthermore, while a handful of scholars have written about the ways in which journalism uses memory (Lang and Lang 1989; Edy 1999; Zelizer 1992; Schudson 1992), news forgetting, though it is often remarked upon (see Bagdikian 2004), does not appear to have been the subject of sustained scholarly attention; neither has news satire been studied from the perspective of memory. This article therefore aims to contribute new insights to three fields: to bring media amnesia and satire to cultural memory studies, amnesia to journalism and media studies, and memory and forgetting to satire studies. The salience of doing this has to do with the hegemonic or counter-hegemonic roles of memory and forgetting in two important cultural forms: news and news satire. The article begins with a brief overview of relevant theories of memory and forgetting, then moves to a discussion of news forgetting before considering the memory work performed by satire.

\section{Memory and Forgetting}

The field of 'cultural', 'social' or 'collective' memory is very dispersed and is approached from disciplines such as sociology, psychology, literary criticism, history, art history, political science and media studies (Olick and Robbins 1998, 106). There has been criticism that the field as a whole has swerved into the territory of trauma and personalised memory, and that this has depoliticised memory studies, which should have at its core questions of power (see Radstone 2005). There are strands of memory research, however, that do focus on the "quintessential sociological" issues of power, hegemony, ideology and stratification (Olick and Robbins 1998, 122), including some of the work on "media memory" (see Meyers et al. 2014), which emphasises the roles 
of different media and genres in cultural memory (though satire has not, to my knowledge, been studied from this angle).

Scholars have approached the workings of memory on different levels. Some theorise memory and/or forgetting on the 'macro' level, in relation to certain phases of capitalism or capitalism itself - as being bound up with the mode of production and accumulation. Adorno and Benjamin (1999) identified a crisis in memory stemming from the forgetting at the heart of the commodity - forgetting of the social relations involved in commodity production. Huyssen (1995) sees postmodern culture as being obsessed with memory. Paradoxically, this obsession comes from a fear of forgetting generated by the acceleration and information overload of late capitalism. Other research focuses on the 'meso' level of individual memory practices and their role in articulating identities and negotiating power relations (Olick and Robbins 1998, 122; Basu 2012; Bijl 2015; Erll 2011; Rigney 2017; De Cesari and Rigney 2014). Connections are not always made between the two levels.

Work within media studies has trodden both terrains. Those using network theory, for example, have seen memory as transforming in the age of Web 2.0 and becoming "connective" rather than "collective" (Hoskins 2009). This work, while concerned with the 'macro' level of memory, tends to emphasise technological innovation rather than social relations. While journalism has been somewhat neglected by memory studies, there is now a body of scholarship on the 'meso' level of journalistic memory practices as well as other media memory practices. Journalistic memory can help negotiate national trauma (Kitch 2011); it can be used by politicians to improve their public image (Berkowitz 2011); or help journalists consolidate their own authority (Zelizer 1992; Schudson 1992). Edy (1999) offers a typology of ways journalists use the past, identifying commemorative journalism, historical analogies and historical context. She analyses the functions of each, the extent to which they enable critical reflection on the past and connect the past with the present. While there is now a collection of work on journalistic memory, there is very little on journalistic forgetting. This is despite the fact that forgetting seems to be a much more conspicuous feature of news than remembering, and can have serious social implications.

\section{News Forgetting}

I will now outline a typology of news forgetting and link this to theories of amnesia as a phenomenon of capitalism, before moving on to explore how news satire "gives the news a memory". As mentioned, some critical theory has identified amnesia as a pervasive feature of capitalism (Kurz 2009; Jameson 2011). Kurz (2009, 30) writes that "the total market system does not merely gloss over its own history; to a great extent it even erases it. 'Homo economicus' has as it were the same perception of time as a small child". This is caused partly by the acceleration that is built into capitalism as a mode of accumulation (Rosa 2015; Fuchs 2015; Harvey 1990): companies are always trying to produce and sell more and faster. Under these speeded-up conditions, reality becomes "liquid" (Bauman 2007), and it is increasingly difficult to orient ourselves in time and space: to remember. The amnesia resulting from acceleration has ideological outcomes. Being unable to remember the past means not having a grip on the present and not being able to conceive of alternative futures. Amnesia thus has the effect of preserving the status quo (see De Cock et al 2012; Jameson 2003).

It is ICTs (Information and Communications Technologies) that have enabled this acceleration (see Hope 2011; Castells 2000; Fuchs 2015). In turn, a feature of the resulting "liquid reality" is the "media torrent" and "information overload" (Gitlin 2001). Just as other companies are speeding up production and exchange, media companies 
are constantly trying to produce more content faster, and the result is a relentless 'torrent' of images and sounds. This is a major contributor to the disorientation people experience in relation to space and time (See Taussig 2006; Huyssen 2000; Rosenberg and Feldman 2008). Taussig $(2006,63)$ writes of "a consciousness so prone to rapid processing of stimuli that it undermines both memory itself and the ability to experience". News media play a crucial role in this "information overload". In the age of 24/7 multi-platform "fast news", news agendas move at "warp speed" (Kovach and Rosenstiel 1999, 5). It has been claimed that this acceleration of news has caused a "collapse in memory" (Hoskins 2004). Thus, journalism is embedded in and contributes to the dynamics of capitalism associated with the acceleration of time, and the resulting amnesia of our age.

The same conditions leading to acceleration, the media torrent, and pervasive social amnesia also lead to specific practices of journalistic forgetting. Many claim that the pressures on journalists in the age of "fast" capitalism (Agger 2004), in which media organisations are focused more than ever on cutting costs and raising revenue, has led to poor quality journalism or "churnalism" (Davies 2009). A number of journalistic practices associated with "churnalism" can be conceptualised in terms of forgetting. These include relying more heavily on official sources, news wire and public relations material; not having time to follow up stories; extreme simplification and not having time or expertise to provide context; and failing to hold the powerful to account, through lack of time, autonomy or resources. These practices lead to content that exhibits multiple modes of forgetting. They have ideological outcomes, if ideology is defined as a system of ideas that can "contribute to establishing, maintaining and changing social relations" (Fairclough 2003, 9; in Devereux 2011, 104). Five types of news forgetting are summarised below. Media scholars have been analysing the first three types for decades from the perspectives of selection, omission and framing. Recasting them in terms of forgetting helps to illuminate them from a new perspective, to understand more fully the ideological roles of news within contemporary "fast" capitalism, and to grasp the relationship between news and news satire in new ways. The fourth and fifth types are more uniquely and complexly to do with forgetting, involving the news erasing and rewriting its own past coverage.

\subsection{The Always Already Forgotten}

Of course, certain events and places never make it into the news. They are always already forgotten. Journalists themselves admit that there are "forgotten countries" (Benthall 1993, 28). In the 'western' world, news outlets rely for most of their international news on just two wire agencies: Associated Press (based in the US) and Reuters (based in the UK) (Davies 2009; Paterson 2007). According to Davies $(2009,104)$, some 80 countries, around $40 \%$ of the world's nations, have no print bureau from either agency. 130 countries have no TV bureau from either agency. "News centres" and "news peripheries" are thus created, largely reflecting the global pecking order of contemporary capitalism (van Ginneken 1998). The forgetting of certain places can be said to have ideological effects, naturalising an imperialistic global economic order. There are also always already forgotten voices, meaning that certain perspectives will be marginalised or omitted altogether, while elite perspectives are universalised. As we will see, satire can "give the news a memory" in the sense of offering alternative perspectives and a critical layer both on stories themselves and the way stories are constructed in the news. It does not, however, tend to remember "forgotten countries". 


\subsection{Oblivion}

When a place or event does make it into the news, usually, after a few days or weeks, it will be promptly forgotten. A number of scholars have pointed out that the nature of news flows, with their emphasis on the very latest happenings, means we are constantly forgetting previous events. Paul Lazarsfeld wrote back in 1941 that "Today we live in an environment where [...] news comes like a shock every few hours; where new news programs keep us from ever finding out the details of the previous news" (in van Ginneken 1998, 109). This process has sped up to the point where the news forgets history almost as quickly as it reports it. Sometimes events will fall quickly into oblivion, in that we won't even remember that they were ever in the news at all. Satire does not usually combat oblivion by offering the kinds of follow-up that the news fails to provide. However, the fact that satires tend to be less disposable than news may mean they can provide this kind of remembering.

\subsection{Forgotten Pasts}

When stories do make the news, there tends to be a chronic lack of historical context. Although Edy, in her 1999 article about journalistic memory cited above, observes examples of past events being used in news to contextualise the present, this is relatively rare. The absence of context is especially conspicuous in television news, which needs to cram each story into a couple of minutes, and moves at a frantic pace. For example, the Glasgow Media Group's study of television news coverage of the Israel-Palestine conflict found that one BBC journalist was actually instructed by his editor not to do "explainers" and to focus on "bang bang stuff" (Philo and Berry 2004, 102). When explanations were given at all they were often "brief and enigmatic" (Ibid., 99). The obsession with the present at the expense of historical context is perhaps the most direct way in which news contributes to capitalism's 'eternal present' more broadly. If we conceptualise the focus on the present in individual stories together with the "media torrent", we can imagine an incessant parade of de-contextualised presents, in which it is impossible for citizens to get their bearings. We will see that satire can help combat this by providing historical context to stories.

\subsection{Rewriting History}

Sometimes events are not always already forgotten or quickly consigned to oblivion. They can stay in the news for months as they develop, and can be regularly recalled over periods of years. A good example is the Iraq War, beginning in 2003. In the UK, politicians still periodically appear on the news claiming that they voted for the war because they trusted the intelligence that Saddam Hussein had weapons of mass destruction that could be deployed in 45 minutes. However, that claim had been strongly disputed prior to the war, and those disputes had been all over the news at the time (O'Neill 2002; Assinder 2002). The politician conveniently forgets this, and the journalist, who presumably has the archive footage at their fingertips, complies with the forgetting. This kind of news forgetting - where news media erases its own past coverage - allows politicians to rewrite history. The idea of rewriting history is not new. What is remarkable is the speed at which this rewriting takes place. The events are only a few years old and well within living memory. One can imagine the kinds of alienation that are generated by the combination of these specific instances of the news forgetting its own coverage and the relentless reiteration of this forgetting in the "media torrent", in which history is swept away in its tide. We will explore an example, in the US context, of a satire using archive footage to combat this kind of forgetting. 


\subsection{Hyper-Amnesia}

An even more extreme form of this phenomenon, of the news forgetting or misremembering its own past coverage, can be seen in the coverage of the economic turmoil afflicting the world since the 2008 financial crash. The author (2018) has carried out a study on the UK news coverage of the economic crisis in its different guises over eight years. The overall findings were that, as the crisis has evolved and mutated, it has been continually reframed in the news. Its causes have been forgotten and reconfigured, and this has helped to naturalise policy-responses - including austerity and 'trickle-down' measures such as tax cuts for the rich, privatisations and deregulation that might have seemed absurd under a different framing. Often the root causes were not reported even at the onset of the crisis, but certainly more so than in the following months and years (Basu 2018). In the case of the Iraq War, the conflict has been in and out of the media eye intermittently since 2002. In the case of the economic crisis, not only are events more recent, but this crisis has never left the public eye - it has been constantly in the media since 2008. Thus, history is being rewritten as it is happening. Even more audaciously, history is being rewritten in full public view. Again, techniques used by news satire, such as using archive footage and 'redaction' can help resist this kind of forgetting. It is to the work of news satire that we turn next.

\section{News Satire}

A scholarly field focusing on popular satire has sprung up in recent years in response to a blossoming of satire around the world, especially on television and online (see Jones 2010; Baym and Jones 2012; Gray et al. 2009; Sandvoss et al. 2012). The word 'satire' is thought to derive from satura as used by Quintilian to denote Roman verse satire. Its origins have been traced back through Rome, ancient Greece and Egypt (Lichtheim 1973). The new scholarship engages with a long tradition in satire studies that reflects on the role of satire in society. Opinions differ widely as to the social functions of satire. Most agree that it is a tool used to mock the powerful (ridicule of vulnerable groups in the form of scapegoating is not usually considered satire, though it is by some. See Jones 2010; Elliott 1960; Kuipers 2015). Some claim satire aims to directly incite action for social change (Quintero 2008, 3). Others, on the contrary, argue that satire plays a conservative role, channelling anger at injustice into an acceptable form of humour (Eco 1984). Still others claim that satire instead plays pedagogical and critical roles (see Test 1991; Griffin 1995; Baym and Jones 2012). Through its subversive humour, satire educates audiences on the subject of its attack, illuminating abuses of power. Developing this strand of thought, we might say that satire can fulfil a counterhegemonic function. The ultimate aim of its pedagogy is to persuade its audience that a certain aspect of society is unjust and to create a consensus critical of that aspect of society. In this way, it might have an indirect link to social change. Of course, a wide range of satire exists, from the banal to the radical (Frye 1957; Basu 2014), and a satire is always contained within its medium, which will itself be shot through with uneven social relations (see Basu 2015). However, for now we can posit that it is at least possible that satire can conceivably fulfil a counter-hegemonic function. Satire, like social memory, has therefore very much to do with questions of power.

The recent work on satire often links the popularity of political and news satire to crises in public trust in politicians and journalists. Jones (2010) goes so far as to argue that what he calls "new political television", with satire at its helm, is leading a challenge to the mainstream news as a privileged site for the production of truth. Being comedy, news satires do not have to abide by the conventions of news and current events programming, and are thus free to provide alternative perspectives and critique. At the 
very least, news satires offer a vent for the confusion, frustration and distrust generated by news. I would like to add a new perspective to the analysis of contemporary popular satire, and argue that news satire can help both critique and make sense of the news, and to some extent counter media amnesia by giving the news a memory via a number of memory practices. I am not arguing that the makers of satire necessarily have memory on their minds, but nevertheless, news satires do often routinely perform memory work. Five memory practices are identified and will be explored below: the use of archive footage; redaction; historical context; tracking the development of news stories over time; and genealogies of the news as an institution. These fall into two categories: those that remember the events reported on by the news, and those that remember the formal conventions of the news itself. The analysis focuses on the 'meso' level of practices and modes of memory but links back to the 'macro' theories of memory, amnesia, acceleration and the "media torrent" described above.

\section{Method}

The remainder of this article analyses the different ways in which news satires give news a memory. It focuses on one show from the US, The Daily Show, and one from the UK, Newswipe. The focus here is on television satires due to the phenomenal success of "new political television". As will be discussed, media convergence means that the TV satires can be readily viewed online (I watched all of them online). But madefor-TV satires tend to have a lot more resources and so will likely be qualitatively different from those made to be posted online. No doubt satires circulating online are interesting from the perspective of memory, and would be a good topic for further research (for example, we collected 55 satirical memes about Donald Trump on Instagram in two days, several of which use memory as part of their satirical strategy).

The two programmes were chosen because they are particularly interesting to analyse from the perspective of memory. No doubt there are other satires that perform important memory work from different parts of the world. Future research could attempt comparative studies. The aim of this article is rather to begin to theorise news and news satire in terms of memory and forgetting, and identify some first patterns of remembering and forgetting. There is a relatively close relationship between the US and UK media cultures. Britain has a rich tradition of satire on both TV and radio, and British satire has often been the inspiration for the US variety (see Gray et al. 2009), while British news satires often take on US news. At the same time, the two programmes are very different in terms of their longevity and reach, and are embedded in two different national media systems. Some of these differences will be drawn out below. Textual analysis was performed on clips chosen for their indication of the types of memory work performed by the satires. The Daily Show will be used to explore memory strategies of using archive footage, redaction, and historical context. Newswipe will be used to exemplify tracking stories over time and genealogies of news as an institution.

\section{The Daily Show}

The Daily Show began on Comedy Central in 1996 but really came into its own in 1999 when John Stewart took the helm as host. It is still going, now with Trevor Noah as host. Touting itself as a fake news show, it actually combines news parody with both ironic and serious discussion of current affairs and straight interviews with public figures. It has a huge following and has become a noteworthy source of news in itself 
(see Jones 2010). It self-consciously aims to fill the democratic deficit left by the mainstream media, and holds to account both the politicians who have been let off the hook by the "fourth estate" and the media itself. It uses memory to do this.

\subsection{Archive Footage}

One critical strategy for which The Daily Show is well-known is its use of archive footage to counter politicians' attempts to rewrite history. During the Iraq War, it became an important site for attempting to manoeuvre through the web of deceit woven by the Bush administration. The use of archive footage was one of the key tactics in doing so. To give one example, the edition from June 21, 2004 covers the 9/11 Commission report, which revealed that the government had been wrong in its claim that there was a connection between Iraq and AI Qaida - a primary justification for the invasion. We are shown a clip from a recent CNBC interview with then-Vice President Dick Cheney, in which he denies that he ever made such a link, insisting he "absolutely never said" that an alleged meeting between a 9/11 hijacker and an Iraqi government agent had been "pretty well confirmed". This then cuts to a shot of Stewart scratching his chin in puzzlement, and then to a replay of Cheney's appearance on NBC's Meet the Press from December 2001, in which he says precisely that the meeting had been "pretty well confirmed". Journalists from the New York Times once asked Stewart how The Daily Show had been so successful at "digging up [news] clips catching the president and other officials contradicting themselves". He responded "A clerk and a video machine", dumbfounded that he was being asked by the most influential newspaper in the world how to be a journalist (Jones 2010).

Instead of complying with the erasure and rewriting of history described above, this kind of remembering tries to resist such rewriting. The Daily Show does not offer ideas that undermine capitalism or its "political supplement", liberal democracy (Žižek 2007). Most popular TV satires defend liberal democratic values against what are seen as abuses by its institutions (see Basu 2014). In this way they can be said to perform a practical immanent critique (Adorno 2003/1951), pointing to the gap between liberal democratic theory and the reality of the public sphere within capitalism. The Daily Show's use of archive footage can be considered counter-hegemonic along two dimensions. It performs an immanent critique, exposing and critiquing the reality of the political system. And it fights the kinds of social amnesia that can lead to political paralysis on the part of citizens.

\subsection{Redaction}

The Daily Show is not just known for playing single clips of archive footage, but for its use of redaction as a key means to expose simultaneously the hypocrisy of politicians and the complicity of the mainstream news media. Redaction involves editing together different pieces of footage. It has been an effective technique during the financial crisis. When, in 2013, $\$ 85$ billion of automatic spending cuts were activated because congress had failed to agree spending and tax reforms, The Daily Show announced the news by redacting the headlines from multiple news programmes. Stewart then begins his commentary by explaining: "The sequester is here, the arbitrary budget cuts that were so onerous congress would never allow the sequester to take effect - remember??" This cuts to redacted footage of five different officials and commentators on different platforms on different dates claiming that the cuts would not take place, ending with Obama stating "it will not happen". Cut back to Stewart who exclaims "of course it willen't!" 
Jones (2010), via John Hartley, points to what he calls a current "redactional culture", whereby citizens and alternative media can participate in "culture jamming". According to Michael Strangelove, "Commercial media inhibits audiences' ability to see interconnections, cumulate information, organise it into patterns, and draw conclusions about actions and consequences within the social system" (quoted in Jones 2010,126). This is particularly true of the financial crisis coverage, which has simultaneously given us a glimpse of the workings of capital and managed to confuse the situation comprehensively through hyper-amnesia, described above. For Jones, redaction can lead "to new truths or the contestation of truths offered by traditional sources" $(2009,134)$. The Daily Show takes such techniques to a mass audience on television, again doing the work of the fourth estate that journalism is supposed to do but rarely does. Similarly to the use of individual clips of archive footage, this kind of memory work both critiques and resists the rewriting of recent history, and might in that double sense be said to play a counter-hegemonic role. By editing together multiple clips, redaction lends additional emphasis, and extra humour, to its critique of and resistance against political amnesia and misremembering. US President Donald Trump has offered a field day for this kind of redactive memory work online (see YouTube 2016; CNN 2016).

\subsection{Historical Context}

The third type of memory work performed by The Daily Show is to provide historical context to particular news items. As Baym (2005) points out, The Daily Show often gives single-issue coverage for as long as eight minutes, "often providing background information and drawing historical linkages of the sort uncommon to television news" (264). Furthermore, Baym explains that Stewart's commentary sits alongside the other segments of the show, including serious, extended interviews with public figures who might be able to shed new light on the issue at hand, and it is through this multiplicity of discursive positions that The Daily Show makes sense of world events. Stewart's interviews are self-consciously dialogic rather than collusive or confrontational, providing more opportunity for important information to surface and be explained. It is this interview style that Baym argues enacts a more "deliberative democracy". In this way, The Daily Show provides a corrective to journalism's chronic lack of historical context, discussed earlier. This serves a pedagogical function, giving viewers the opportunity to learn more about current events. In addition, as before, in countering amnesia it helps provide some orientation in time that is crucial to the ability to understand the present and possibly imagine alternative futures.

\section{Newswipe}

Newswipe is a British satire by Charlie Brooker, who is a well-known figure in the UK and is best known internationally for his dystopian sci-fi series Black Mirror. Newswipe ran for two series in 2009 and 2010, with six episodes in each series. Brooker also does a yearly Wipe on BBC2 every January in which he satirically dissects the year's stories. Although Newswipe was only a small BBC4 production, it has had disproportional influence, with one segment entitled "How to Report the News" receiving more than 2.5 million views on YouTube. It combines loose parody, sophisticated discussion of the workings of news, and absurdist - often obscene - humour, which frequently deteriorates into Brooker shouting "Fuck off!" at the TV. Its stated aim is to try and make sense of "what the bloody hell's been going on" in the bizarre world of news. The set alternates between a mock newsroom and Brooker's own living room, in which he watches TV from his sofa. As well as Brooker's narratives, the show contains packages from comedians, academics and journalists about aspects of the news. In addition to 
offering context and a critical layer on top of news stories, Newswipe also deconstructs the conventions of news itself, through its memory work.

\subsection{Tracking News Stories over Time}

In the pilot episode, Brooker discusses the conflict in Georgia in 2009, which "dominated the headlines all week much like a rhino would dominate a school photograph". Like other "forgotten countries", Georgia was a place about which few people in the UK or US, including journalists, knew very much, and which only popped into the news because of a conflict that potentially affected the West. In a few seconds Brooker manages to give more historical context than the television news provided in any single edition during the whole conflict:

While the pictures may have been simple, the background to the conflict wasn't, because everything to do with the Caucasus is incredibly complicated. It's a region heaving with pipelines, place names that resemble Countdown conundrums, and a bodge of geographical boundaries drawn up years ago by Stalin that don't reflect the competing ethnic interests underneath. (Brooker 2009b)

This historical introduction of the Georgian conflict is then followed by an in-depth analysis of how the events had been reported over the past week, tracking the development of news coverage of a particular story over time. This is a benefit of the programme's format as a weekly series: each episode can chart a development within news coverage over a number of days, carrying out a kind of mapping that can help viewers resist being swept up in the media torrent. This is unlike The Daily Show and other big US satires like The Colbert Report, which air almost daily and might therefore be seen as contributing to the media torrent (this issue is explored further in the conclusion). Brooker begins by explaining that when the war broke out, most foreign correspondents were in Beijing covering the Olympics, so newsrooms were forced to rely on newswires and press releases for their information. Partly for this reason, the pro-western, media-savvy Georgian premiere, Mikheil Saakashvili, was immediately painted as the hero of the conflict. The good and bad guys having been established, Brooker explains how the emphasis then shifted to the danger and excitement of it all. Spectacular news clips are set against the theme tune from Rocky, and intercut with Brooker on his sofa saying things like "Awesome!" and "Intense!" in the kind of American accent you would hear in a trailer for a Hollywood movie. This rapidly cuts to disturbing images of injured and dead people and Brooker deflatedly saying "Oh".

The next development we are shown - through redacted footage from news channels from both the UK and US - is the way in which reference to the Cold War crept in and began to dominate. After showing a collection of reporters asking "Are we witnessing the start of a new Cold War?", Brooker replies, "I don't know but with any luck if you keep saying it maybe we will". The segment ends with a piece about public relations: Georgia had apparently issued almost hourly press releases to help state its case. The segment on Georgia lasts about six minutes, during which we are treated to two modes of memory work: historical context of the events themselves (as explored 
in relation to The Daily Show), and charting how the news coverage of the events developed over a period of time.

The technique of remembering how news stories develop over time is a regular feature of the show. Along with the Georgian conflict, Newswipe also tracks the development of news narratives about the 2010 Haiti earthquake and the G20 protests in London 2009, as well as charting the posthumous smear campaign waged against Jean Charles de Menezes, an innocent man who was shot in the back and killed by police after a terror scare. It is very important because it creates the space to understand how news narratives can morph over time (as in the case of the economic crisis and "hyperamnesia" described above), whose interests this can serve, and the factors behind this, and to find some footing amidst these rapidly shifting and forgetful narratives. In doing so, it also serves a critical-pedagogical function, informing viewers about some of the problematic features of journalism discussed earlier on, such as the herd-like behaviour of journalists, the role of PR, 'infotainment' and extreme simplification. This kind of memory work is therefore resistant in the double sense described above. It performs an immanent critique, comparing how liberal democratic institutions (in this case journalism rather than politics) should work with how they do work. And it provides some degree of orientation within the media torrent.

Had the reader of this article forgotten about the conflict in Georgia? As mentioned, news satires do not tend to remember that which is "always already forgotten" - they are based on the big news stories. Nor do they intentionally retrieve stories from oblivion. However, satires are less disposable than news. The clip of Newswipe on Youtube referred to above was first uploaded in 2010 and if the comments are anything to go by is still being viewed in 2017. Both The Daily Show and Newswipe (and many other TV satires) are available to buy on DVD or on iTunes. There is a question, then, of whether news satires can counter the amnesia of oblivion. This is not to do with the format of the satire or memory strategies embedded in its content, but to do with its modes of reception: its durability compared with news.

\subsection{News Genealogies}

The segments tracking the development of news coverage over a few days often sit alongside a fifth and final type of memory work performed by news satires: longer term genealogies of the news as an institution. Since the focus of Newswipe is television news, these genealogies usually stretch back to the beginnings of television. Examples are the history of news graphics, news scares, and the relationship between politicians and journalists. The genealogies usually take the form of Brooker briskly explaining the given aspect, set against fast-cut archive footage spliced with the show's own, usually ridiculous, graphics illustrating what is being said. Brooker will include humorous and often insulting elements into his narrative, and will occasionally disrupt the flow of information to shout profanities at the television or at the viewer.

In the final episode of the first series, a history of the press is given. Brooker begins: "Once upon a time the news used to be printed on sheets of 'paper' using something called 'ink'". He explains that since the beginning of the twentieth century the press has had to keep pace with young "whippersnapper" technologies such as radio and particularly television, and has thus been forced to switch focus away from breaking the news towards "snazzy photographs and human interest pieces". He goes on to explain that the rise of the Internet and the ensuing depletion of newspaper advertising revenues have rapidly accelerated the shift from newspapers as news vessels to "lifestyle comics". The mid-market press is full of scare stories, house prices and moral 
campaigns, while the tabloids have become "violently dispiriting celebrity gossip rags". Moving on to broadsheets, Brooker continues,

The quality press for its part has a demented emphasis on opinion pieces [...] and when they're not full of that they're running wanky lifestyle features about which expensive designer shoe goes best with your organic food delivery [...] (2009a)

Brooker then goes on to discuss the migration of newspapers online, where not enough money is being generated to meet costs, so that many titles are cutting back and some local papers are closing down altogether. In short, "being a newspaper journalist right now must be about as much fun as gargling cold cow piss for a living". These genealogies thus address issues to do with "fast news" and "churnalism" described in the first part of this article. They also offer a kind of 'meta-memory' that reminds us that the news is a construct that changes over time, and that it cannot be understood apart from the historical socio-economic processes in which it is embedded. In this sense, Newswipe abides by Fredric Jameson's (2002) first rule to beat the alienation caused by capitalist amnesia: "always historicise!" Again, then, its memory work can be described as doubly resistant.

\section{Conclusion}

Rather than helping viewers to understand the events it reports, modern news renders it impossible to make sense of what is happening in the world. This is in part due to the multiple patterns of forgetting built into its flows, which are in turn caused by political economic factors. Whole countries are always already forgotten, or sporadically rise from and fall back into journalistic oblivion. Historical context is forgotten. Politicians are permitted to rewrite histories so recent they are barely even past. News narratives continually forget themselves. Mainstream news can be said to follow the logic of instrumental reason (Horkheimer 1947). Fuchs (2014) writes that within mainstream media there are both economic and ideological dimensions of instrumental reason, with news commodification and advertising on the one hand and the narrowly circumscribed and therefore distorted version of the world presented in news on the other. The two are of course linked. We can add a more abstract level of analysis to this by considering the temporal aspect. Economic instrumentality leads to faster news and the "media torrent", which in turn not only presents a distorted version of reality but short-circuits the ability of people to orient themselves within and process reality.

In response to this crisis in journalism, news satires have risen up around the world. They both mock the news and try to make sense of it, both in terms of its conventions and the events it reports. A crucial way they do this is by giving the news a memory. The five memory practices discussed were the use of archive footage; redaction; supplying historical context to news items; tracking how particular stories develop over time; and providing historical narratives of the news as an institution. The mode of mocking humour in which this memory work is performed is essential. Through satiric strategies of mimicry, exaggeration, irony and juxtaposition, satire interrogates and educates. Moreover, perhaps it is the humour which makes the satires themselves so memorable: studies show that humorous material tends to be recalled at higher rates than non-humorous material (Carlson 2011). Meanwhile, audiences tend to forget broadcast news almost immediately (Gunter 1990; Nordenstreng 1971, in Glasgow 
University Media Group 1976, 10). By giving the news a memory, these "fake news" satires can therefore help combat the ideological effects of both "fake news" and "real news".

The "new political television" scholars with whom I have been engaging do not claim that the work done by these television satires is radical, and neither do I. Neither of the satires discussed want to overcome liberal democracy or capitalism. Moreover, there is the question of whether it is even possible for a medium as top-down as television to offer an art which is revolutionary (see Basu 2015). Something similar could be said about satire online, given the control of the Internet by vast corporations (see McChesney 2014; Curran et al. 2016). These programmes - especially the huge US ones like The Daily Show - are very much part of the dynamics of capitalism producing amnesia. It is no coincidence that these are on TV almost daily and are therefore contributing to the temporality of the "media torrent". Indeed, the flourishing of satire TV in the US was enabled by the same developments that have ratcheted up acceleration in the neoliberal era: "a changing technological infrastructure that allowed for a large number of channels to deliver diversified programming via cable and satellite, widespread access to digital technologies of production and distribution, and the conglomeration and integration of ownership over multiple media platforms" (Imre 2012, 131).

However, the memory work these satires perform can be considered at least partially resistant in a double sense. In response to the instrumental reason of mainstream media, it performs an immanent critique of (neo)liberal democracy. And it gets us closer to a kind of "cognitive mapping" (Jameson 1991), helping people make sense of the news by orienting themselves a little in respect to its forgetful flows. In any case, at the very least, these satires can remind us that we are not the only ones shouting at our TV sets.

\section{References}

Adorno, Theodor W. 2003/1951. Cultural Criticism and Society. In Can One Live after Auschwitz? A Philosophical Reader, edited by R. Tiedemann. Stanford: Stanford University Press.

Adorno, Theodor W, and Walter Benjamin. 1999. The Complete Correspondence 1928-1940. Cambridge: Harvard University Press.

Agger, Ben. 2004. Speeding up Fast Capitalism. Boulder: Paradigm Publishers.

Assinder, Nick. 2002. Blair's Case for the Prosecution. BBC News Online, 24 September.

Bagdikian, Ben H. 2004. The New Media Monopoly. Boston: Beakon Press.

Basu, Laura. 2018 [In press]. Media Amnesia: Rewriting the Economic Crisis. London: Pluto.

Basu, Laura. 2015. TV Satire and its Targets: Have I Got News for You, The Thick of It and Brass Eye. In The Power of Satire, edited by Marijke Meijer Drees and Sonja De Leeuw. Amsterdam: John Benjamins: 207-216.

Basu, Laura. 2014. Who can take a joke? Life of Brian, Four Lions, and the religious 'humour scandal'. Relegere: Studies in Religion and Reception 4 (2): 177-206.

Basu, Laura. 2012. Ned Kelly as Memory Dispositif: Media, Time, Power, and the Development of Australian Identities. Berlin: De Gruyter.

Bauman, Zygmunt. 2007. Liquid Times. Cambridge: Polity Press.

Baym, Geoffrey. 2005. The Daily Show: Discursive Integration and the Reinvention of Political Journalism. Political Communication 22: 259-276.

Baym, Geoffrey and Jeffrey P. Jones, eds. 2012. Special issue: Not Necessarily the News? Global Approaches to News Parody and Political Satire. Popular Communication 10 (1-2).

Benthall, Jonathan. 1993. Disasters, Relief and the Media. London: Tauris.

Berkowitz, Dan. 2011. Telling the Unknown through the Familiar. In On Media Memory, edited by Motti Neiger, Oren Meyers and Eyal Zandberg. Basingstoke: Palgrave Macmillan. 
Bijl, Paul. 2015. Emerging Memory. Amsterdam: Amsterdam University Press.

Brooker, Charlie. 2009a. Newswipe series 1, episode 1. BBC4.

Brooker, Charlie. 2009b. Newswipe series 1, episode 6. BBC4.

Carlson, Kieth A. 2011. The Impact of Humor on Memory: Is the Humor Effect about Humor? Humour: International Journal of Humour Research 24 (1): 21-42.

Castells, Manuel. 2000. Information Technology and Global Capitalism. In On the Edge: Living with Global Capitalism, edited by Will Hutton and Anthony Giddens, 57-75. London: Jonathan Cape.

Curran, James, Natalie Fenton and Des Freedman. 2016. Misunderstanding the Internet. Oxon: Routledge.

CNN. 2016. Trump vs Trump. Accessed 5 January 2018. https://edition.cnn.com/videos/politics/2016/06/10/donald-trump-contradictions-origwx-bw.cnn

Davies, Nick. 2009. Flat Earth News. London: Vintage.

De Cesari, Chiara and Ann Rigney. 2014. Transnational Memory: Circulation, Articulation, Scales. Berlin: de Gruyter.

De Cock, Christian, Leanne Cutcher and David Grant. 2012. Finance Capitalism's Perpetually Extinguished Pasts. Culture and Organization 18 (2): 87-90.

Devereux, Eoin. 2011/2007. Media Studies: Key Issues and Debates. London: Sage.

Eco, Umberto. 1984. The Frames of Comic Freedom. In Carnival!, edited by Thomas Sebeok. New York: Mouton.

Edy, Jill A. 1999. Journalistic Uses of Collective Memory. Journal of Communication 49: 7185.

Erll, Astrid. 2011. Memory in Culture. Basingstoke: Palgrave Macmillan.

Fenton, Natalie. 2010. Drowning or Waving? In New Media, Old News, edited by Natalie Fenton. London: Sage.

Frye, Northrop. 1957. Anatomy of Criticism: Four Esays. Princeton: Princeton University Press.

Fuchs, Christian. 2015. Culture and Economy in the Age of Social Media. Oxon: Routledge.

Fuchs, Christian. 2014. Social Media: A Critical Introduction. London: Sage.

Gitlin, Todd. 2001. Media Unlimited. New York: Metropolitan Books.

Glasgow University Media Group. 1976. Bad News. London: Routledge \& Kegan Paul.

Gray, Jonathan, Jeffrey P. Jones and Ethan Thompson. 2009. The State of Satire, the Satire of State. In Satire TV, edited by Jonathan Gray, Jeffrey P. Jones and Ethan Thompson, 336. New York: NYU Press.

Griffin, Dustin H. 1995. Satire: A Critical Reintroduction. Kentucky: University Press of Kentucky.

Gunter, Barrie. 1990. Poor Reception. Oxon: Routledge.

Harvey, David. 1990. The Condition of Postmodernity. Oxford: Blackwell Publishers.

Hope, Wayne. 2011. Crisis of temporalities: Global capitalism after the 2007-08 financial collapse. Time and Society 20 (1): 94-118.

Horkheimer, Max. 1947. Eclipse of Reason. New York: Continuum.

Horvit, Beverly. 2004. International News Agencies and the Pre-War Debate. In Global Media go to War, edited by Ralph D. Berenger. Spokane: Marquette Books.

Hoskins, Andrew. 2009. Digital network memory. In Mediation, Remediation, and the Dynamics of Cultural Memory, edited by Astrid Erll and Ann Rigney. Berlin: de Gruyter.

Hoskins, Andrew. 2004. Television and the Collapse of Memory. Time and Society 13 (1) 109-127.

Huyssen, Andreas. 2000. Present Pasts: Media, Politics, Amnesia. Public Culture 12 (1): 2138.

Huyssen, Andreas. 1995. Twilight Memories: Marking Time in a Culture of Amnesia. London: Routledge. 
Kurz, Robert. 2009. Schwarzbuch Kapitalismus. Ein Abgesang auf die Marktwirtschaft [second edition]. Frankfurt am Main: Eichborn. Translation by Josh Robinson in process.

Imre, Anikó. 2012. The Witty Seven: Late Socialist-Capitalist Satire in Hungary. Popular Communication 10: 131-144.

Jameson, Fredric. 2011. Representing Capital: A Reading of Volume One. London: Verso. Jameson, Fredric. 2003. The End of Temporality. Critical Inquiry 29 (4): 695-718.

Jameson, Fredric. 2002. The Political Unconscious. Oxon: Routledge.

Jameson, Fredric. 1991. Postmodernism, or the Cultural Logic of Late Capitalism. Durham: Duke University Press.

Jones, Jeffrey P. 2010. Entertaining Politics: Satiric Television and Political Engagement. Plymouth: Rowman and Littlefield Publishers.

Jones, Jeffrey P. 2009. Believable Fictions. In The Changing Faces of Journalism, edited by Barbie Zelizer. New York: Routledge.

Kitch, Carolyn. 2003. Mourning in America: Ritual, Redemption, and Recovery in News Narrative after September 11. Journalism Studies 4 (2): 213-224.

Kovach, Bill and Tom Rosenstiel. 1999. Warp Speed: America in the Age of Mixed Media. New York: Century Foundation Press.

Kuipers, Giselinde. 2015. Satire and Dignity. In The Power of Satire, edited by Marijke Meijer Drees and Sonja de Leeuw, 19-32. Amsterdam: John Benjamins.

Lang, Kurt and Gladys E. Lang. 1989. Collective Memory and the News. Communication 11: 123-129.

Le Masurier, Megan. 2015. What is Slow Journalism? Journalism Practice 9 (2): 138-152.

Lichtheim, Miriam. 1973. Ancient Egyptian Literature: Volume I. California: University of California Press.

McChesney, Robert. 2014. Digital Disconnect. New York: The New Press.

McChesney, Robert. 1999. Rich Media, Poor Democracy. Urbana: University of Illinois Press.

Meyers, Oren, Eyal Zandberg and Motti Neiger. 2014. Communicating Awe: Media Memory and Holocaust Commemoration. London: Palgrave McMillan.

Neiger, Motti, Oren Meyers and Eyal Zandberg, eds. 2011. On Media Memory. Basingstoke: Palgrave Macmillan.

Olick, Jeffrey and Joyce Robbins. 1998. Social Memory Studies. Annual Review of Sociology 24: 105-140.

O’Neill, Brendan. 2002. Blair's Dodgy Dossier. Spiked, 24 September. http://www.spikedonline.com/newsite/article/4905\#.WmH9PieQzCl

Paterson, Chris. 2007. International News on the Internet: Why More is Less. Ethical Space: The International Journal of Communication Ethics 4 (1/2): 57-66.

Philo, Greg and Mike Berry. 2004. Bad News from Israel. London: Pluto.

Quintero, Ruben. 2008. Introduction: Understanding satire. In A Companion to Satire, edited by Ruben Quintero. Malden, MA: Blackwell Publishing.

Radstone, Susannah. 2005. Reconceiving Binaries: The Limits of Memory. History Workshop Journal 59: 134-151.

Rigney, Ann. 2017. The Afterlives of Walter Scott. Oxford: OUP.

Rosa, Hartmut. 2015. Social Acceleration. New York: Columbia University Press.

Rosenberg, Howard and Charles F. Feldman. 2008. No Time to Think. New York: Continuum.

Sandvoss, Cornell., C. Lee Harrington and Jonathan Gray. 2012. Special Issue: Not Necessarily the News? Global Approaches to News Parody and Political Satire. Popular Communication 10 (1-2).

Schifferes, Steve. 2015. Why the public doesn't trust the business press. In The Media and Financial Crises: Comparative and Historical Perspectives, edited by Steve Schifferes and Richard Roberts, 153-168. Oxon: Routledge. 
Schudson, Michael. 1992. Watergate in American Memory. New York: Basic.

Sotos, Rachael. 2007. The fake news as the fifth estate. In The Daily Show and Philosophy, edited by Holt, John. Malden: Blackwell Publishing: 28-40.

Taussig, Michael. 2006. Walter Benjamin's Grave. Chicago: University of Chicago.

Test, George A. 1991. Satire: Spirit and Art. Florida: University Press of Florida. van Ginneken, Jaap. 1998. Understanding Global News. Thousand Oaks: Sage.

YouTube. 2016. Trump exposes Trump. YouTube video, 23 July. Accessed 5 January 2018. https://www.youtube.com/watch?v=kSE-XoVKaXg

Zelizer, Barbie. 1992. Covering the Body. Chicago: University of Chicago Press.

Žižek, Slavoj. 2007. Democracy is the enemy. London review of books [blog post]. Retrieved from http://www.Irb.co.uk/blog/2011/10/28/slavoj-zizek/democracy-is-the-enemy/

\section{About the Author}

\section{Laura Basu}

Laura Basu is a writer and researcher affiliated with the Communications and Media department at Goldsmiths, University of London, and the Institute for Cultural Inquiry, Utrecht University. She writes on a range of issues to do with culture, society, economics and politics. Her book Media Amnesia: Rewriting the Economic Crisis (Pluto Press) and her edited volume The Media and Austerity (Routledge) are both coming out in April 2018. 